\title{
The Challenges Facing Small-Scale Women Entrepreneurs: A Case of Kenya
}

\author{
Fridah Muriungi Mwobobia \\ Limkokwing University of Creative Technology- Botswana \\ Business \& Globalization Faculty \\ P.O. Box 10313 \\ Gaborone-Botswana \\ Tel: +267-722-59682Ｅ-mail: joyfredahmuriungi@yahoo.com
}

Received: December 12, 2011 Accepted: February 19, 2012 Published: March 15, 2012

doi:10.5430/ijba.v3n2p112

URL: http://dx.doi.org/10.5430/ijba.v3n2p112

\begin{abstract}
The study sought to identify the challenges facing small scale women entrepreneurs in Kenya and initiatives put in place to counter the challenges. The study employed desktop research. MSEs Baseline survey, recorded that 612,848 women in Micro and Small Enterprises (MSEs) in Kenya, accounting for 47.4 per cent of all those in MSEs. The study showed that women tended to operate enterprises associated with traditional women's roles, such as hairstyling. The small and micro enterprises (SMEs) play an important role in the Kenyan Economy such as creating jobs however they face serious challenges such as lack of finance, discrimination, problems with the city council, multiple duties, poor access to justice, lack of education, among others. The study established that many stakeholders from both public and private sector are helping empower women entrepreneurs in Kenya: such as formation of women enterprise fund, establishing of women's university of science and technology, formal and informal financial support, and donor initiatives among others have been put in place. The study recommends that women in entrepreneurs need to be accepted and supported financially, legally and more capacity building should be made available. Further research is recommended in this area.
\end{abstract}

Keywords: Women Entrepreneurs, Challenges, Small and Micro-Enterprises (Smes), Initiatives to Empower, Kenya

\section{Introduction}

Women entrepreneurs in Kenya are the key to economic growth because they are generating employment. But womenowned businesses could contribute more than what they are doing today. A growing amount of research shows that countries that fail to address gender barriers are losing out on significant economic growth. Without increased attention to the gender dimensions of economic development, Kenya is therefore unlikely to meet its growth targets. This therefore demonstrates that addressing gender barriers in Kenya could generate significant economic growth for the country. The Kenyan government recognizes that women entrepreneurs have not been on an equal footing when it comes to their access to opportunities and assets but it has yet to effectively address the barriers facing women in business (Athanne, 2011).

Women entrepreneurs around the world are making a difference. They contribute numerous ideas and a great deal of energy and capital resources to their communities, and generate jobs as well as create additional work for suppliers and other spin-off business linkages (Common wealth secretariat, 2002).

Siwadi and Mhangami (2011) adds that it is undeniable that women entrepreneurs are the major actors in that sector and contributors to economic development and are becoming increasingly visible in the local economies of the developing counties.

Promoting women's economic and political empowerment has gained greater attention over the last three decades (Yeshiareg Defene, 2007).

According to the 1999 National MSEs Baseline survey, there were 612,848 women in Micro and Small Enterprises (MSEs) in Kenya, accounting for 47.4 per cent of all those in MSEs. The results showed that women tended to operate enterprises associated with traditional women's roles, such as hairstyling, restaurants, hotels, retails shops and wholesale outlets. 
In general, women tended to operate smaller enterprises than men, with the average number of employees in a women-owner/manager MSE being 1.54 versus 2.1 in men -owner/managed MSEs. In women -owner/managed MSEs, about 86 per cent of workers were women owner/managers themselves, 4 per cent were hired workers, with the remainder made up, of unpaid family members and /or apprentices. Whereas, in men-owner/managed MSEs, only 68 per cent of the workers were men owner/managers themselves, 17 per cent hired workers and the remainder made up of unpaid family members and /or apprentices.

Kenya's private sector (agriculture, industry and services) amounts to 81 percent of GDP and provides more than half of the formal wage employment. It's the informal sector and the MSEs in it which have created almost all of the new jobs in Kenya's economy last year, comparatively these micro-enterprises account for 53 percent of all jobs in Europe and 30-45 percent in Botswana (LEA 2007). Most MSEs are disadvantaged private sector players; current relationship within the private sector must change for more productive business interaction. This requires opening up of access to formal financial and non -financial services a process of education and capacity development of smaller business and above all, trust building between the larger firms and their smaller suppliers and marketers. All this requires active facilitation and resources. (Economic survey 2006).

According to ILO study carried out by Steven son and St-ONge (2005), there are three profiles of women entrepreneurs operating MSEs in Kenya, namely those in Jua Kali micro-enterprises, "very small" micro-enterprises and "small-scale" enterprises. These are differentiated by their demographic profiles, extent of previous business experience, needs, access to resources and growth orientation. Most of the rural women provide for their families through subsistence farming and other agricultural activities supplemented by petty trade or micro enterprises. But they continue to face challenges.

\subsection{Statement of the Problem}

The small and micro enterprises (SMEs) play an important role in the Kenyan Economy. According to the Economic Survey (2006), the sector contributed over 50 percent of new jobs created in the year 2005. Despite their significance, past statistics indicate that three out of five businesses fail within the first few months of operation (Kenya National Bureau of Statistics, 2007). According to Amyx (2005), one of the most significant challenges is the negative perception towards SMEs. Potential clients perceive small businesses as lacking the ability to provide quality services and are unable to satisfy more than one critical project simultaneously. Often larger companies are selected and given business for their clout in the industry and name recognition alone.

Women owned businesses are known for their low start up and working capital (Siwadi etal 2011, Glen 2003) note that under normal circumstances women's enterprises have low growth rate and limited potential partially due to the type of business activities they run. The question then is, apart from financial problems and low growth what other challenges face the women entrepreneurs in Kenya?

Women entrepreneurs face many problems. Kimathi (2009) emphasize that small businesses are held back by tough local conditions some of them are unable to raise huge collaterals demanded by banks as a condition to access loans. This has created an impression that they are too big for microfinance institutions but too small for conventional banks. Could this be the greatest challenge faced by the women entrepreneurs in Kenya? This study seeks to explore more.

\subsection{Research Objectives}

This study purely seeks to find out:

i) What problems/ challenges are facing small- scale women entrepreneurs in Kenya

ii) In what industries are these small-scale women entrepreneurs engaged in

iii) What measures have been put in place by the Kenyan government and other institutions to assist such small-scale women entrepreneurs

iv) What can be recommended in future for small-scale entrepreneurs in Kenya and other developing countries

\section{Methodology}

To meet the research objectives the study employed desktop research by reviewing relevant texts, websites, journals, magazines and newspapers.

\section{Literature Review}

\subsection{Defining Small and Micro Enterprises}

A micro-enterprise (or microenterprise) is a type of small business, often registered, having five or fewer employees and requiring seed capital of not more than $\$ 35,000$. The term is often used in Australia to refer to a business with a single owner-operator, and having up to 20 employees. The European Union_EU defines micro-enterprises as those that meet 2 of the following 3 criteria and have not failed to do so for at least 10 years: 
- fewer than 20 employees

- balance sheet total below $\$ 800,000$ US

- $\quad$ turnover below 800000 US

(http://en.wikipedia.org/wiki/Micro-enterprise)

Mugwara (2000) defines small and micro enterprises as businesses owned by individual entrepreneur who employs one person to twenty people as the business grows.

To (Bowen,Morara \& Mureithi, 2009) it can be inferred that small and micro businesses are dominated by people with relatively low levels of education.

Entrepreneurs are widely recognized as the prime movers of economic development; the people who translate ideas into action. An interesting though not widely accepted definition of an entrepreneur is a person who has the ability to scan and identify opportunities in his or her environment, gather the resources necessary to take advantage of the opportunities and implement successful action to utilize the opportunities.

In Kenyan, context, small enterprises are those businesses that have 10-50emplyees, whereas medium enterprises are those businesses that employ 51-99 people. (Ongori \& Migiro, 2011; Migiro, 2006).

Ahmad, Xarier, perumal and Nor (2011) defines women entrepreneur as a woman who have initiated a business, is actively involved in managing it, and owns at least $50 \%$ of the firm and have been in operation one year or longer.

This definition identifies an entrepreneur by their behavior rather than the specific occupation they are involved in. Those who have studied entrepreneurial behavior have noted certain characteristics such as innovativeness, ability and willingness to take calculated risks, determination, insight, total involvement, independence, need for achievement, leadership ability and among others Githeko Jason (2005)

\subsection{Fators influencing small and micro enterprises}

Starting and operating a small business includes a possibility of success as well as failure. Because of their small size, a simple management mistake is likely to lead to sure death of a small enterprise hence no opportunity to learn from its past mistakes. Lack of planning, improper financing and poor management have been posited as the main causes of failure of small enterprises (Longenecker, et al., 2006). Lack of credit has also been identified as one of the most serious constraints facing SMEs and hindering their development (Oketch, 2000; Tomecko \& Dondo, 1992; Kiiru, 1991).

Education is one of the factors that impact positively on growth of firms (King and McGrath, 2002). Those entrepreneurs with larger stocks of human capital, in terms of education and (or) vocational training, are better placed to adapt their enterprises to constantly changing business environments (King and McGrath, 1998). Infrastructure as it relates to provision of access roads, adequate power, water, sewerage and telecommunication has been a major constraint in the development of SMEs (Bokea, Dondo \& Mutiso, 1999).

\section{Challenges Facing Women Owned Small and Micro Enterprises in Kenya}

The experiences the women entrepreneurs have in running their businesses include such problems as lack of enough capital, difficulties in transportation and marketing, the perishability of some commodities and competing demand related to household chores, difficulties in licensing procedures, finding staff with the right skills, willing to work for a small firm can be a problem, as is ensuring they have the time to update their skills and keep up with developments in the field. (http://ec.europa.eu/enterprise/policies/sme/promoting-entrepreneurship/crafts-micro-enterprises/)

\subsection{In Adequate Access to Finance}

The greatest barrier facing women entrepreneurs in Kenya is access to finance is an issue because of requirements of collateral. In Kenya only $1 \%$ of women own property and that makes it very difficult for women to provide collateral for banks. Most women who venture into businesses in the rural areas and need financing lack the needed collateral to enable them secure bank loans. Responsibility of entrepreneurs for dependants has limited opportunities to make savings or undertake business expansion and diversification Athanne (2011). The financial aspects of setting up a business are without doubt the biggest obstacles to women (Zororo 2011, Brush 1992).

Women entrepreneurs often lack information about how to get a loan, lack the necessary collateral to obtain one and /or face discriminatory laws or practices related to finance and credit Common wealth secretariat (2002)

Finding the finance to get a new business going, or to grow an existing one is a difficult challenge. (http://ec.europa.eu/enterprise/policies/sme/promoting-entrepreneurship/crafts-micro-enterprises/) 
Makokha (2006) adds that women entrepreneurs have financial social demands that compete with business capital, leading to a diversion of capital away from business needs.

Kinyanjui (2006) records that some entrepreneurs felt that it was difficult to obtain loans as they had to show credit records and they did not fully understand the requirements getting and paying loans.

Loans from Kenyan microfinance institutions tend to be limited in amount, have no grace period, are short term in design and carry very high interest rates. Consequently, most women entrepreneurs are likely to have multiple short-term loans to cater for both businesses and social needs. Studies have shown that loans to MSE entrepreneurs only satisfy a fraction of their financial needs (Women Entrepreneurs in Kenya, 2008).

Formal financial support is seen to be too expensive for many women entrepreneurs and hence they treat this as a last resort. (Stevenson and St-Onge, 2005).

\subsection{Discrimination}

Another challenge that women entrepreneurs in Kenya face is discrimination. Even when women entrepreneurs do approach banks for financing, they tend to face discrimination. Women report that bank officials tend to ignore them in meetings and prefer speaking to their husbands or male business partners. The fact that banks engage in gender bias prevents many women from even approaching them. Some women get so discouraged that they do not bother to seek bank financing and turn instead to informal savings groups.

Gray (1996) adds that the women's major problem during the start-up is the credit discrimination. A woman is not allowed to open a bank account or own land without her husband's or father cosignatory. Although inheritance laws were revised with the succession Act of 1981, women have rarely inherited land and other property in their own right. This means that they lack title deeds which are still the most commonly used form of security for borrowing money.

Women own only 1 percent of Kenya's land (5-6 percent) is held under joint names usually with husband . (World Bank report)

Entrepreneurship always involves some level of risk taking. For women in the rural areas, gender stereotyped perception of self, lack of confidence and assertiveness appear to be major barriers. The fear to risk is a big hindrance.

The status of women in a patriarchal social structure makes women dependent on males in their lives -husbands or fathers -and family resistance is a major disincentive to business start-up. Other close male family members often make decisions for women hence going against the independent spirit of entrepreneurship.

In addition, women are usually less educated than men, making them less well equipped to manage a business Common wealth secretariat (2002).

\subsection{Dealing with the City Council}

City council has proved to be a very big challenge to women entrepreneurs in Kenya. The licenses are too many and the cost too much. Being a woman seems to exaggerate that fact since most women are harassed by the city council officials when they come to inspect the business premises. Moreover, women may be less likely to meet and negotiate bribes with the predominantly male council officials. Business licensing is an issue for many women entrepreneurs who perceive the process as lengthy and complex Athanne (2011).

Bindra (2006) adds many Kenyan MSEs are covered by some formal registration, the cost of such registration is nominal but entrepreneurs find the procedures to be followed and information about offices to be visited for requisite forms and registration to be confusing. There is no "one-stop shop" which inform an aspiring entrepreneur what is required of him or her in terms of regulations to be followed for licensing.

\subsection{Multiple Responsibilities}

One other challenge is the responsibility of providing for the extended family and relatives. Most micro-enterprise financial resources are not usually isolated from personal finances and hence these family obligations are met from resources earned in the business. Their demands tend to drain the savings and income made by the business, since such finances would otherwise have been used in the enterprise for expansion and growth. Though some of them do assist in providing services in the enterprise (or in the family), the financial obligations in supporting them usually exceeds the services they provide.

Ahmad etal (2011) adds that women are overloaded with business and family responsibilities and may not have the time to join these beneficial associations and this automatically limits the women entrepreneurs' wings of exploration. 
Common wealth secretariat (2002) adds that when business training is available, women may not be able to take advantage of it because it is held at a time when they are looking after their family. Comparative studies show that women start business at an older age than men, when they have had the family and children (Zororo 2011, Green and Cohen 1995), this becomes a great challenge.

The rural women appear not to be driven by profits but rather, by the need to provide for their families. They see enterprises as a means of setting them free from 'begging' from their spouses money for the basic necessities of their families - food, clothing and health. What they earn is totally spent for the benefit of the entire family. Another key motivating force for women to become business owners has been identified as interest in helping others. Generally women entrepreneurs in small scale business receive substantial family support at start-up and in the course of running their business. Such support is however, based mainly on social rather than economic consideration.

\subsection{Poor Access to Justice}

Access to justice is essential for ensuring, smooth business operations, and it spans issues such as enforcing contracts and employment disputes. Yet women entrepreneurs in Kenya have difficulties when assessing justice. Using the formal courts in Kenya can be costly, complex and time consuming for entrepreneurs. For women who are burdened with their multiple responsibilities in the household and at work and who do not have the know-how to navigate the government process, dealing with the complicated and often corrupt bureaucracy is another challenge, Athanne (2011).

Common wealth secretariat (2002) records that women often have few or no contacts in the bureaucracy, and there may be a bias against women's businesses. Women have little representation on policy -making bodies, partly because they tend not to belong to or reach leadership positions in mainstream business organizations.

\subsection{Lack of Education}

Lower education levels puts women entrepreneurs in Kenya at a disadvantage compared to men. While gender gap in primary education in Kenya has decreased in recent years, the gap remains high at secondary and tertiary education levels. Lower education does not emphasize entrepreneurship skills. It decreases the chances that women will have the knowledge needed to excel in business, and thereby contribute to the country's overall economic growth.

In education, preference is given to boys, thus the educational level of most women entrepreneurs is very low, creating a barrier to them accessing training and other business developments services. (Women entrepreneurs in Kenya, 2008).

Lack of sufficient education and training for women is another impediment to micro-enterprise success. Culturally, and especially in the rural setting, the girl child was not given equal opportunity to study like the boys; hence they had limited education and training (if any) which tends to affect effective performance in later life. One woman laments:

"We are isolated socially; we lack previous work experience, and access to enterprise information and marketing facilities which the men entrepreneurs acquire. The excessive demand on our time as wives, mothers and 'managers' of the home front due to our chores, make it nearly impossible to successfully operate an enterprise. It is only by God's grace that we manage to survive. This is besides our position in the family and the structure of power relations. One who ventures out there to follow the entrepreneurial spirit, does so at the expense of her family. "(Women entrepreneurs in Kenya, 2008).

In addition, women are usually less educated than men, making them less well equipped to manage a business (Common wealth secretariat, 2002).

Namusonge (2006) noted that entrepreneurial education and training play a key role in stimulating entrepreneurship and self-employment.

Despite the presence of Business Development services in Kenya not many women entrepreneurs use it because of cost, access, necessity, or availability (Steven etal 2005).

\subsection{Managing Employees}

Managing employees is another challenge that women entrepreneurs in Kenya face. Finding and retaining good employees is essential for the success of a business, but can be difficult for women entrepreneurs in Kenya. Since women owned-owned businesses tend to be smaller, they are often less likely to provide job security and retain good talent. Some women find that they are not taken seriously by their employees, especially in non-traditional sectors, and have to make a special effort to win their respect Athanne (2011).

\subsection{Competition}

Whilst micro-enterprises are very often the source of innovation, they are also especially vulnerable to competition from counterparts who introduce new products or services, or improve their production processes, lacking the resources to 
respond rapidly. Competition (markets) and information related factors, are said to be major challenges. Competition is seen in form of the size of market share in the rural setting. Most of these markets are not expanding and new competitors such as mini-super markets with wide varieties of products for those who were engaged in selling household products are emerging. To Jaiyeba (2010) this could be caused by lack of marketing skills.

\section{Efforts Being Made to Empower Women Entrepreneurs in MSEs in Kenya}

Several interventions are being carried out by a number of stakeholders to ensure that the sector plays its role fully. Both the Government and the private sector (including the NGOs) are engaged in various efforts to empower the entrepreneurs in particular women, to grow their enterprises. The following are the interventions;

\subsection{Formation of Women Enterprise Fund (WEF)}

Women Enterprise Fund (WEF) was conceived by the Government of Kenya in 2006 and officially launched in 2007. The principal objective of the fund is economic empowerment of women. Women Enterprise Fund loans reach the target beneficiaries through the partner financial intermediaries and directly through Constituency Women Enterprise Scheme (C-WES).

This fund is aimed to enable the government realize the 3rd Millennium Development Goal (MDG) on "gender equality and empowerment of women". In recognition of the critical role women play in socio-economic development, the WEF has been identified as a flagship project under the social pillar in the Vision 2030. It is expected that the fund will play a catalystic role in mainstreaming women in the formal financial services sector.

Although women constitute 52 percent of the total Kenyan population, majority of them have been excluded from the formal financial services - for example, few have bank accounts, can access loans, money transfer services, etc. The rural women are more disadvantaged than their urban counterparts.

The fund is designed to address the perennial challenges women face in their desire to venture in income generating activities (enterprise development), namely:

i. Cultural factors - The society does not allow women to own assets which are required by banks to access credit. Some widows are disinherited by in-laws.

ii. High transaction costs - a) Interest rates and bank charges b) Access costs - transport costs.

iii. Myths about banks - Few banks have outlets in the rural areas. The society's negative perception about banks e.g. repossession of assets incase of default, not "poor" friendly, etc. (http://www.gender.go.ke/index.php/Women-Enterprise-Fund-WEF/intro-women-enterprise-fund-wef.html)

\subsection{Establishment of a Women's University Of Science and Technology}

The establishment of Keriri Women's University of science and Technology is one of the positive affirmative actions taken to empower women in MSEs. This gives young women a chance to study science and Technology, the foundations for creativity and innovation and elements essential for growth of MSEs. This gives women more access to technical education hence empowers them to enter MSEs. On the hand, the public universities, the entry qualification for women, for all degree programs has always been a point lower, as part of an affirmative action scheme. This allows for educational opportunity for women. There is an assumption that with the knowledge and skills acquired in life, women graduates will have a better chance of being entrepreneurial. (Women entrepreneurs in Kenya, 2008)

\subsection{Formal Financial Support for MSEs}

In Kenya, formal financial support is provided by commercial Banks, Non Governmental Organizations (NGOs), Microfinance Institutions (MFIs) and Savings and Credit Co-operatives Societies (SACCOs) among others. These employ an integrated approach, disseminating information and building capacity of women's groups in effective management of revolving funds.

In so doing, they use Women Economic Empowerment Consort (WEEC), an Microfinance institution targeting women at the grassroots level and in different areas mainly in Kajiado District in Rift Valley Province and in two other districts in Central Province and Kenya Rural Enterprises Program (K-REP) which operates various micro-financing schemes from the K-REP Bank. Among them are the Juhudi, Chikola and Katikati loan schemes, supporting men and women entrepreneurs. (Women entrepreneurs in Kenya, 2008)

K-REP uses both group based approach and individual lending, about 50 percent of the total portfolio is for group based and the rest is retail or individual lending. The collateral in the group approach is "social collateral" -group guarantee. Repayment rates on such loans have consistently been very high with an extremely low about 2 percent default rate. (Central Bank of Kenya, 2006). 


\subsection{Finance from Mainstream Commercial Banks}

Most commercial banks have special products for MSEs, in most cases offered along with other normal banking facilities however concerns have been raised as to the conditions of access to them and the cost of money borrowed. Cooperative Bank of Kenya its financial support ranges between KES 15,000 (US 4205) to KES 300,000 (US\$ 4, 110) repayable in six months.

Other formal banks lending to SMEs are Standard Chartered, Stanbic and Commercial Bank of Africa or offering wholesale credit to the MFIs. (Central Bank of Kenya, 2006).

\subsection{Informal Financial Support}

Informal financial support services include several variations on Merry-Go- Rounds (MGRs) and Rotating and Services Credit Associations (ROSCAS )which have roots in traditional mutual guarantee systems. A typical ROSCA involves a group of 5-10 members and operates on simple principles, namely, regular meetings where each member contributes agreed amounts of money and each member gets a turn as the recipient with no interest charged on the loan or earned savings.

5.6 The Role Played by the NGOs

NGOs play a major role in empowering MSEs. Organizations such as Care International, World Vision, Plan International are working such as relief and welfare, technical innovation, national development, public health, agriculture, advocacy, grassroots development agencies and other networks which are highly helping the MSEs in Kenya.

\subsection{Business Development Services}

Business development services comprise non- financial services that are aimed at capacity building. They include training services, marketing and institutional support. Management training of MSEs focuses on building the capacity of entrepreneurs, by transferring of relevant knowledge and skills needed to successfully run the enterprise. These include skills in financial management, marketing, human resources management and entrepreneurship training. In Kenya the Institutions offering such are Christian Industrial Training Centers (CITC's), Federation of Kenya Employers (FKE) Voluntary Service Overseas (VSO) Kenya Institute of Management (KIM), Jomo Kenyatta University of Agriculture and Technology (JKUAT), the national polytechnics, the Kenya Institute of Business Training (KIBT) and a number of NGOs using donor funding.

\subsection{Access to Infrastructure}

According to 1999 National MSE Baseline survey, efforts made to alleviate the problem of infrastructure are; construction of industrial area in Buru Buru in Nairobi by NCCK, construction of Nyayo Sheds by the ministry of Research, Technical Training and Technology and the construction of 600 sheds in five urban areas by the Government of Kenya with assistance from the German Society of technical Cooperation (GTZ) and the current Government Rural-Electrification program.

The recent establishment of courier companies such as Securicor Courier and Easy Coach courier services, and the coming of safaricom and Celtel mobile phones have also helped to improve infrastructure.

\subsection{Donor Initiatives}

In Kenya donor strategy for supporting MSEs has been mainly that of using intermediaries, such as NGOs and Government, many microfinance institutions are funded by donors for lending on to entrepreneurs such as Kenya women Finance Trust (KWFT), Ecumenical Church Loan Fund(ECLOF) and K-REP. Some commercial banks also act as intermediaries to extend credit to the MSEs either under loan guarantee schemes or other arrangements for example Association of Microfinance Institutions (AMFI) which is an umbrella organization for microfinance institutions in Kenya and receives funding from United States Agency for International Development (USAID) for its operations. Among the key donors supporting women's entrepreneurship are; the Japanese International Corporation Agency (JICA), GTZ, USAID and United Nations Development Programme (UNDP).

JICA is supporting women in agriculture, specifically in horticulture, in several areas of the country through training. The training is conducted by Jomo Kenyatta University of Science and Technology, GTZ is a bilateral donor which works through the Government and is supporting agriculture in Kuria district.

USAID programmes insists that MFIs continuosly increase the percentage of women they serve. It supports KWFT which offers financial services to women and supports several MFIs through concerted support for the AMFI.

UNDP through the co-financing effort of EU, implemented bee-keeping project in Kibera slum women. 
The ILO/AFDB growth oriented women entrepreneurs programme being implemented by IFC will pave the way for women entrepreneurs to receive business planning training and loans to support the growth of their business.

\subsection{Regional Center for Enterprise Development (RCED)}

The SBCs have local perspectives with each assigned specific geographical areas of operation. The need for a center with a national and regional perspective was fulfilled by the fledgling RCED which is one of its kind in Africa. This Center is based at the Jomo Kenyatta University College of Agriculture and Technology situated about half an hour north of Nairobi. The Center's activities' are geared towards entrepreneurship, managerial and extension oriented research, entrepreneurship studies and technological research; consultancy, rural enterprise development, small and medium enterprise, information dissemination and appropriate technology, and conduct of industry dialogues, conferences and appreciation seminars. It is a center of excellence and innovation in the field of small, medium and large enterprise training, promotion and development' (RCED brochure). The Center has a Small Business Center (or Unit) as part of its activities with the SBC functions being similar to those of SBCs at technical training institutions (TTI). (http://www.africa.upenn.edu/Comp_Articles/SBC_Network_12727.html)

\section{Recommendations}

Basing on the desktop findings, the following is recommended:

i) To fight poverty in Kenya (and the continent as such), the pivotal place of women in society (specifically in rural areas) needs to be accepted and supported. They need capacity building and training in functional areas such as finance, literacy skills, marketing, production and managerial skills. A mind shift among their spouses (and the men in general) should also be encouraged so that they give full support besides embracing the changing role of women in the homes.

ii) Married women should be given support by their spouse in respect of finances, motivational encouragement, advice and actual involvement in the running of business.

iii) Access to credit by women entrepreneurs at the level of micro and small-scale enterprises, should be facilitated through innovative programs and financing arrangements that go beyond the conventional approaches; which require collateral and capital among other conditional ties.

iv) The public sector and formal financial organizations should be sensitized on the value of gender-balanced participation in the informal sector enterprises. A major goal should be to promote the social and economic empowerment of women, as they constitute a vulnerable social category that is critical in sustainable development endeavors.

v) Micro finance institutions should portray a non gender based environment in order to stimulate women entrepreneurs in Kenya to do business with them

vi) The registration officers should be more friendly and available for service to all, particularly the City council officials should refrain from harassing women in business.

vii) Women entrepreneurs in Kenya should be taught on the value of being independent. This will stimulate them to do things on their own like acquiring property.

viii) Strategies should be put in place with different instruments to address access to finance issues for women, like mentoring them, helping them prepare proposals for bank funding and even providing a guarantee for them.

ix) Support Research and Development on SMEs and market information systems.

\section{Further Research}

Based on the findings, further research is recommended in this area especially on the accessibility of financial aid by small and micro enterprises women entrepreneurs in Kenya. 


\section{References}

Ahmad, S. Z., Xavier, S. R., Perumal, S., Nor, M. L. \& Mohan, C. J. (2011).The transition from corporate Careers to business ownership: The case for women entrepreneurs in Malaysia. International Journal of Business Administration, vol.2, No.3, 2011. http://dx.doi.org/10.5430/ijba.v2n3p148

Amyx,C.(2005). Small Business challenges- The perception problem: Size Doesn't matter. Washington Business Journal.

Athanne (2011). Entrepreneurship in Kenya, Nairobi .

Bindra S. (2006). "Doing Business in Kenya still too hard", The Sunday Nation, Nairobi.

Bowen, M., Morara, M. \& Mureithi, S. (2009). Management of Business challenges among small \& Micro enterprises in Nairobi- Kenya: KCA. Journal of Business Management vol. .2

Central Bureau of statistics (1999). ICEG and K-REP, National MSE Baseline

Central Bureau of statistics (1999). National Micro and Small Enterprise Baseline survey results . Conducted by the Central Bureau of Statistics (CBS), International Centre for Economic Growth (ICEG) and K-REP holdings Ltd, Nairobi:Kenya.

De Bruin, A., Brush, C. \& Weller, F. (2007). Advancing a framework for coherent Research on Women's Entrepreneurship. Entrepreneurship Theory and practice. Vol 3 no.3

Gakure, R. W. (2003). "Factors Affecting WEs Growth prospects in Kenya," Prepared for the International Labor Organization (ILO) Geneva.

Gary, D., Phillip, C. \& Joan, A., (1998). "Strategic performance model", Empowerment in organizations. Vol.6 no.2,1998. http://dx.doi.org/10.1108/14634449810210742

Green, E. \& Cohen, L. (1995). Women's business: Are women Entrepreneurs Breaking New Ground or simply Balancing the Demands of women's work in a new way? Journal of Gender studies, Vol.4 no. 3

Gupta, A., Koshal, M. \& Koshal R. (2006). Women managers in India: Challenges and opportunities. In H. J. Davis, S. R. Chatterjee \& M. Heuer(Eds.), Management in India. New Delhi: Response Books.

Hisrich \& Brush (1986). Women and minority Enterpreneurs. A comparative analysis. Frontiers of Entrepreneurship.

Jaiyeoba, O. (2010). The Impact of market orientation on SMMEs in the developing economies: a case of Botswana. International Journal of Business Administration. http://dx.doi.org/10.5430/ijba.v2n3p132

IFC and the World Bank, Voices of Women Entrepreneurs in Kenya, Washington DC

International labour organization (2008) Women Entrepreneurs in Kenya. Geneva; Switzerland ISBN:9789221204800;9789221204817

Kenneth, R. G. (1996). A strategic Analysis of manufacturing sector in Kenya: Entrepreneurship In Micro-enterprises; University press of America. ISBN: 0761801405/9780761801405

Kimathi, J. (2009). Going it alone. Msafiri. November 2009-January 2010 : Edition 69

Kinyanjui, M. N.,(2006). "Overcoming barriers to Enterprise Growth: The experience of MSEs in Rural Central Kenya" Nairobi, Kenya.

Langowitz, N. \& Minniti, M. (2007). The entrepreneurial propensity of women. Enterepreneurship Theory and practice . Vol31 no.3

MC Kay, R. (2001). Women Entrepreneurs,Moving beyond family and flexibility. International Journal of entrepreneurial Behavior and Research, Vol.7 no.4 148-165

Mugwara, D. (2000). Small and medium enterprise policy \& strategy: Ministry of Industry \& Commerce.

Oketch, H. O. (2000). Gender equity. In A.Mullie and Bokea (Eds).. Micro and Small Enterprises in Kenya: Agenda for improving the policy Environment. Nairobi. ICEG.

Ongori, H. \& Migiro S. O. (2011). Enhancing SMEs competitiveness: The strategies to resolve Barriers to information communication technologies adopted by SMEs. A paper presented in 2011 International Conference on Innovation and Growth: University of Botwsana.

Peter, K. (2005). Resource Banking Meeting, Kenya Institute of management. 
Republic of Kenya, (2006). Economic survey, the Government printer, Nairobi: Survey, Nairobi: Kenya.

Ronge, E., Ndirangu, L. \& Nyangito, H. (2002). Review of Government policies for promotion of Microand small scale enterprises in Kenya. KIPPRA Discussion paper.

Shekari, H., Rabiee, A., Afshari, M. and Ahanim, (2011). Using effective factors in Employees Empowerment of industrial organizations with Analytical Network Approach (ANP). casestudy: Textile factories of Qom province. International Journal of Business Administration. http://dx.doi.org/10.5430/ijba.v2n3p160

Siwadi, P., Mhangami, M. (2011). An analysis of the performance of women entrepreneurs in a Multi-currency economy: The case of Midlands province of Zimbabwe: University of Botswana Journal.

Smith, B. (1997). Empowerment the challenge is now, Empowerment I Organizations Journal, Vol.5, No.3,http://dx.doi.org/10.1108/14634449710180008

Stevenson 1, St-Onge, A. (2005). "Support for growth -Oriented Women Entrepreneurs in Kenya". International Labour Organization, Geneva.

Temecko. J. \& Dondo, A. (1992). Improving the potential of small scale and informal sector Nairobi: K-REP and GTZ.

Walsh, F. M \& Likinski, J. (2009). The role of the marketing function in small and medium sized enterprises. Journal of small business enterprise development. http:// dx.doi.org/10.11o8/1462600091100029

World Bank (2001). Engendering Development Through Gender Equality in Rights, Resources \& Voice.

Zororo, M. (2011). Characteristics and Motivation in Female Entrepreneurship . Case of Botswana. University of Botswana Journal.

http://en.wikipedia.org/wiki/microenterprise accessed on 28/11/11

http://ec.europa.eu/enterprise/policies/sme/promoting-enterpreneurship/crafts-micro-enterprises.accessed on 1/12/11

http://business reviewkenya.com/4072/journal- mgmt-information-systems. accessed on 2/12/11

http://businessreviewkenya.com/1483/challenges-facing-kenya-entrepreneurship accessed on 26/11/12

http://www.africa.upenn.edu/Comp_Articles/SBC_Network_12727.html accessed on 3/12/11

http://www.edworldwide.org/the-challenges-facing-young-entrepreneurs-in-kabete-kiambu-kenya-a-case-study/(http://e n.wikipedia.org/wiki/Micro-enterprise). 